\title{
Varietal differences in quality characteristics of popped rice
}

\author{
Madhuri Kotagi, N. Surekha, Ravikumar S. Naik and N.B. Yenagi
}

Rice is a versatile cereal and used for consumption in various forms. The three principal rice products of commercial importance which are traditionally being made in India are popped, puffed and flaked rice. Popped rice is a popular product, especially in Asia, because of its crispness and lightness. Hence an investigation was undertaken to study the varietal suitability of rice for popping quality characteristics. Sample of 15 paddy varieties were procured from ARS, Mugad. The physico-chemical parameters, cooking time and gelatinization temperature (GT) of milled rice and popping quality such as popping yield, expansion ratio of popped rice and flake size of popped rice were studied. Physical characteristics of milled rice varieties varied significantly $(\mathrm{P}<0.01)$. Among the milled rice varieties, the super fine variety Pusa-basumati had the highest length $(7.22 \mathrm{~mm})$ and the lowest in Dodiga $(5.33 \mathrm{~mm})$ a common grain variety. The L:B ratio for all the varieties of milled rice ranged from 1.89 to 3.68 . In the study the popping yield was positively correlated with thousand kernel weight $(\mathrm{r}=0.332)$, bulk density ( $\mathrm{r}=0.605)$, head rice yield $(\mathrm{r}=0.571)$, whereas the popping expansion was positively correlated to $\mathrm{L}: \mathrm{B}$ ratio $(\mathrm{r}=0.527)$ and no significant correlation was found between popping expansion and amylose content and gelatinization temperature. The expansion ratio of popped rice of Intan found to be maximum at 27.6 per cent total amylose and 13.4 per cent hot water insoluble amylase. In the present study, it was observed that rice varieties Intan, Dodiga Udarsali, Navali, Abhilash, Jaya, Champakali posses good processing quality, exhibit optimum cooking time (19.00 to $23.50 \mathrm{~min})$, high amylose content $(27.6-30.6 \% \mathrm{db}$ ) and intermediate gelatinization temperature $\left(70.09^{\circ}\right.$ to $\left.72.45^{\circ} \mathrm{C}\right)$. Hence, it can be concluded that the rice varieties with high amylose content and intermediate gelatinization temperature are most suitable for good cooking, eating and processing qualities.

Key Words : Popped rice, Flake size, Expansion ratio, Gelatinization temperature, Amylose

How to cite this article : Kotagi, Madhuri, Surekha, N., Naik, Ravikumar S. and Yenagi, N.B. (2016). Varietal differences in quality characteristics of popped rice. Food Sci. Res. J., 7(1): 1-9.

\footnotetext{
MEMBERS OF RESEARCH FORUM

Author for correspondence :

MADHURI KOTAGI, Department of Foods and Nutrition, College of Rural Home Science, University of Agricultural Sciences, DHARWAD (KARNATAKA) INDIA

Email : madhuri_kotagi@yahoo.com

Associate Authors' :

N. SUREKHA AND N.B. YENAGI, Department of Foods and Nutrition, College of Rural Home Science, University of Agricultural Sciences, DHARWAD (KARNATAKA) INDIA

Email : surekhan_1980@rediffmail.com; niryenagi@yahoo.co.in

RAVIKUMAR S. NAIK, Department of Agricultural Economics, University

of Agricultural Sciences, DHARWAD (KARNATAKA) INDIA

Email : ravinaik_cci@rediffmail.com
} 